\title{
Prenylbicyclogermacrane Diterpenoids from the Formosan Soft Coral Nephthea pacifica
}

\author{
Ali A. H. El-Gamal, ${ }^{\dagger}$, Shang-Kwei Wang, ${ }^{\S}$ Chang-Feng Dai, ${ }^{\perp}$ I-Gin Chen,${ }^{\dagger}$ and Chang-Yih Duh ${ }^{*, \dagger}$ \\ Department of Marine Resources, National Sun Yat-sen University, Kaohsiung, Taiwan, Republic of China, Department of \\ Microbiology, Kaohsiung Medical University, Kaohsiung, Taiwan, Republic of China, and Institute of Oceanography, National \\ Taiwan University, Taipei, Taiwan, Republic of China
}

Received July 23, 2004

Ten new prenylbicyclogermacrane diterpenoids, pacificins A-J (1-10), were isolated from the methylene chloride solubles of the Formosan soft coral Nephthea pacifica. The structures were elucidated by $1 D$ and 2D NMR spectral analysis, and their cytotoxicity against selected cancer cells was measured in vitro.

Soft corals of the genus Nephthea are rich in terpenoids ${ }^{1-11}$ and steroids. ${ }^{12}$ As part of our search for bioactive substances from marine organisms, the Formosan soft coral Nephthea pacifica Kükenthal (family Nephtheidae) was studied as $\mathrm{CH}_{2} \mathrm{Cl}_{2}$ extracts and showed significant cytotoxicity to A549 (human lung adenocarcinoma), HT-29 (human colon adenocarcinoma), and P-388 (mouse lymphocytic leukemia) cell cultures as determined by standard procedures. ${ }^{13,14}$ Bioassay-guided fractionation resulted in the isolation of 10 new prenylbicyclogermacrane diterpenoids, pacificins $\mathrm{A}-\mathrm{J}(\mathbf{1}-\mathbf{1 0})$.

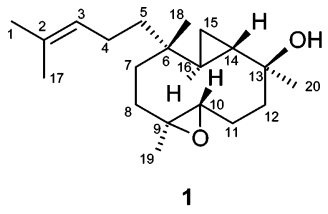

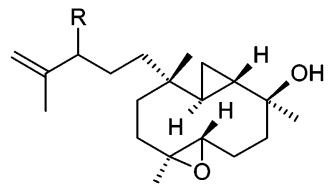

$4, \mathrm{R}=\mathrm{OH}$ $5, \mathrm{R}=\mathrm{OOH}$

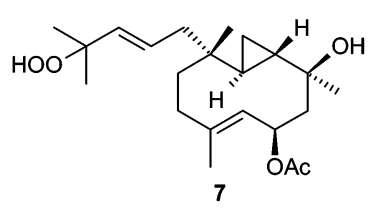<smiles>C=C1CC/C=C(/C)CC[C@]12CC21CC1CCC=C(C)C</smiles>

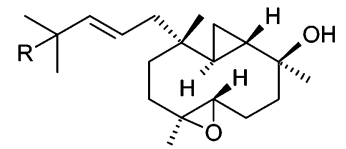

2, $\mathrm{R}=\mathrm{OH}$ $3, \mathrm{R}=\mathrm{OOH}$<smiles>CC/C(C)=C\CC[C@@]1(C/C=C/C(C)(C)O)CC1[C@](C)(O)CC</smiles>

6
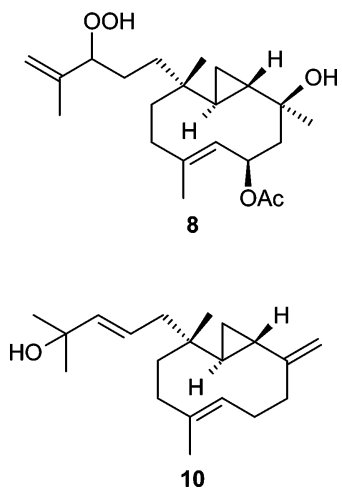

\section{Results and Discussion}

Pacificin A (1) was isolated as a colorless amorphous solid. HREIMS, ${ }^{13} \mathrm{C}$ NMR, and DEPT spectra established

* To whom correspondence should be addressed. Tel: 886-7-525-2000, ext. 5036. Fax: 886-7-525-5020. E-mail: yihduh@mail.nsysu.edu.tw.

National Sun Yat-sen University.

* On leave from Faculty of Pharmacy, Mansoura University, Egypt.

$\S$ Kaohsiung Medical University.

${ }^{\perp}$ National Taiwan University. the molecular formula of $\mathbf{1}$ as $\mathrm{C}_{20} \mathrm{H}_{34} \mathrm{O}_{2}$, with four degrees of unsaturation. ${ }^{13} \mathrm{C}$ NMR and DEPT spectra of $\mathbf{1}$ exhibited the presence of four methyls, seven $\mathrm{sp}^{3}$ methylenes, three $\mathrm{sp}^{3}$ methines, one $\mathrm{sp}^{2}$ methine, three $\mathrm{sp}^{3}$ quaternary carbons, and one $\mathrm{sp}^{2}$ quaternary carbon. The presence of two $\mathrm{sp}^{2}$-hybridized carbon atoms in the molecule, as deduced from the ${ }^{13} \mathrm{C}$ and DEPT NMR spectra (Table 2), corresponding to one carbon-carbon double bond as the only double bond, indicated compound 1 to be tricyclic. The presence of a trisubstituted epoxy group in $\mathbf{1}$ was shown by the NMR data $\left(\delta_{\mathrm{H}} 2.81 \mathrm{~d} ; \delta_{\mathrm{C}} 61.9 \mathrm{qC}, 66.2 \mathrm{CH}\right)$ (Tables 1 and 2). The NMR data $\left(\delta_{\mathrm{H}} 0.20 \mathrm{~m}, 0.38 \mathrm{~m}, 0.73 \mathrm{~m}, 1.10\right.$ $\mathrm{m} ; \delta_{\mathrm{C}} 3.9 \mathrm{CH}_{2}, 27.1 \mathrm{CH}, 28.8 \mathrm{CH}$ ) (Tables 1 and 2) pointed to a cyclopropane ring in 1 . The ${ }^{1} \mathrm{H}$ NMR spectrum also contained signals for five tertiary methyl groups $\left(\delta_{\mathrm{H}} 0.46\right.$, $0.73,1.30,1.58,1.65)$. In addition, a signal at $\delta_{\mathrm{H}} 5.06$ was attributed to an olefinic proton and was confirmed by ${ }^{13} \mathrm{C}$ NMR spectroscopy $\left(\delta_{\mathrm{C}} 125.0 \mathrm{CH}\right)$. The presence of an ambiguous carbon bearing an oxygen $\left(\delta_{\mathrm{C}} 72.9 \mathrm{qC}\right)$ was shown in the ${ }^{13} \mathrm{C}$ NMR spectrum. The spectral data of $\mathbf{1}$ exhibited some similarity to those of a prenylbicyclogermacrane diterpenoid, palmatol, isolated from Alcyonium palmatum ${ }^{15}$ except for the differences of chemical shifts in the vicinity of $\mathrm{C}-9 / \mathrm{C}-10$. Measurement of the ${ }^{13} \mathrm{C}-{ }^{13} \mathrm{C}$ homonuclear shift correlation 2D spectrum (INADEQUATE) (Supporting Information) of $\mathbf{1}$ together with COSY, HMQC, and HMBC (Figure 1) experiments established its chemical structure and enabled also the assignment of all resonances in the NMR spectra. The relative stereochemistry of $\mathbf{1}$ was deduced from a 2D NOESY experiment (Figure 2), which indicated that $\mathrm{Me}-19, \mathrm{Me}-20$, and $\mathrm{H}-16$ were on one side of the molecule, while Me-18, $\mathrm{H}-10$, and $\mathrm{H}-14$ were on the opposite side of the molecule. From these data, pacificin A can be formulated as $\mathbf{1}$.

The molecular formula of pacificin $\mathrm{B}(2)$ proved to be $\mathrm{C}_{20} \mathrm{H}_{34} \mathrm{O}_{3}$ by HREIMS and ${ }^{13} \mathrm{C}$ NMR data. Detailed comparison of ${ }^{1} \mathrm{H}$ and ${ }^{13} \mathrm{C}$ NMR spectral data (Tables 1 and 2) of 2 and 1 revealed that 2 differed from 1 in the side chain. COSY correlation between $\mathrm{H}-3 / \mathrm{H}-4$ and $\mathrm{H}-4 / \mathrm{H}-5$, HMBC correlations from $\mathrm{H}-1 / \mathrm{H}-17$ to $\mathrm{C}-2 / \mathrm{C}-3$ and $\mathrm{H}-5$ to $\mathrm{C}-3 /$ C-6/C-7, and a $J_{3,4}$ of $15.6 \mathrm{~Hz}$ placed an $E$ double bond between C-3 and C-4. The relative stereochemistry of $\mathbf{1}$ was determined by a 2D NOESY experiment, which indicated that $\mathrm{Me}-19, \mathrm{Me}-20$, and $\mathrm{H}-16$ were on one side of the molecule, while $\mathrm{Me}-18, \mathrm{H}-10$, and $\mathrm{H}-14$ were on the opposite side of the molecule. From the aforementioned data, pacificin B can be formulated as $\mathbf{2}$.

Pacificin C (3) had the molecular formula $\mathrm{C}_{20} \mathrm{H}_{34} \mathrm{O}_{4}, 16$ mass units higher than that of 2 . The ${ }^{1} \mathrm{H}$ and ${ }^{13} \mathrm{C}$ NMR 


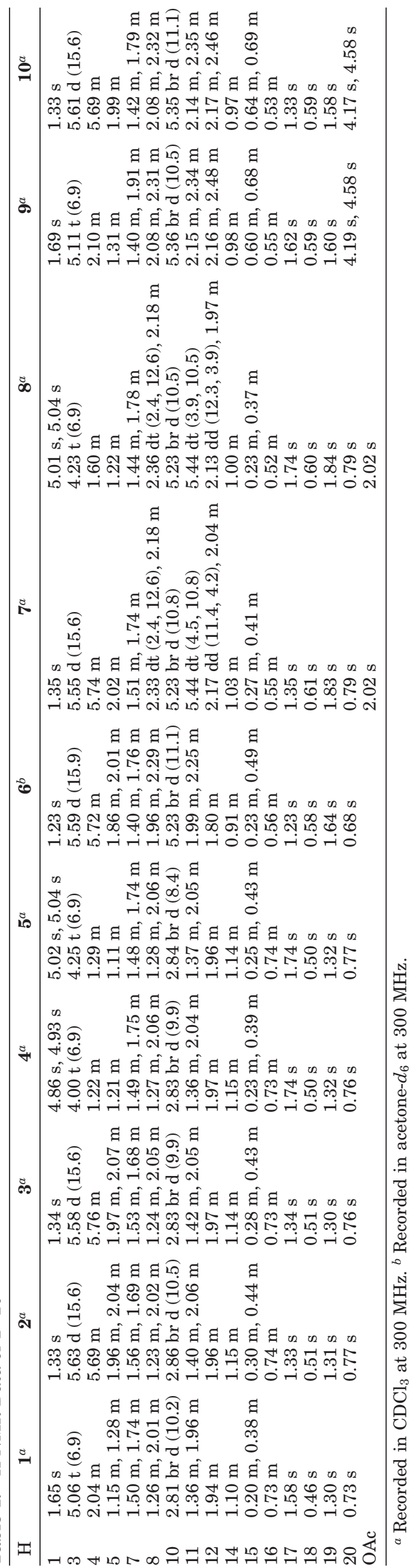

spectral data (Tables 1 and 2) closely resembled those of $\mathbf{2}$ except that the tertiary hydroxyl attached to $\mathrm{C}-2$ was replaced by a hydroperoxide. HMBC correlations from $\mathrm{H}-1 /$ $\mathrm{H}-17$ to $\mathrm{C}-2 / \mathrm{C}-3$ and $\mathrm{H}-5$ to $\mathrm{C}-3 / \mathrm{C}-6 / \mathrm{C}-7$ confirmed the position of the hydroperoxide. The relative stereochemistry of 3 was deduced from a 2D NOESY experiment, which indicated that $\mathrm{Me}-19, \mathrm{Me}-20$, and $\mathrm{H}-16$ were on one side of the molecule, while Me-18, $\mathrm{H}-10$, and $\mathrm{H}-14$ were on the opposite side of the molecule. From these data, pacificin C was formulated as $\mathbf{3 .}$

HREIMS and NMR data revealed pacificin D (4) to have a molecular formula of $\mathrm{C}_{20} \mathrm{H}_{34} \mathrm{O}_{3}$. The ${ }^{1} \mathrm{H}$ and ${ }^{13} \mathrm{C}$ NMR spectral data exhibited the presence of a terminal methylene $\left(\delta_{\mathrm{H}} 4.86,4.93 ; \delta_{\mathrm{C}} 111.8,147.3\right)$ and a secondary hydroxyl $\left(\delta_{\mathrm{H}} 4.00 ; \delta_{\mathrm{C}} 76.9\right)$. The ${ }^{1} \mathrm{H}$ and ${ }^{13} \mathrm{C}$ NMR spectral data of 4 (Tables 1 and 2) closely resembled those of 1 except for NMR signals due to the side chain. HMBC correlations from $\mathrm{H}-17$ to $\mathrm{C}-1 / \mathrm{C}-2 / \mathrm{C}-3$ confirmed the 3-hydroxyisopentenyl side chain. The relative stereochemistry of 4 was establised by a 2D NOESY experiment, which indicated that $\mathrm{Me}-19, \mathrm{Me}-20$, and $\mathrm{H}-16$ were on one side of the molecule, while Me-18, $\mathrm{H}-10$, and $\mathrm{H}-14$ were on the opposite side of the molecule. Therefore, the structure of pacificin D was established as 4 .

Pacificin E (5) was isolated as a colorless resin of molecular formula $\mathrm{C}_{20} \mathrm{H}_{34} \mathrm{O}_{4}$, as indicated by HRFABMS and NMR spectra. The ${ }^{1} \mathrm{H}$ and ${ }^{13} \mathrm{C}$ NMR spectral data (Tables 1 and 2) were very close to those of $\mathbf{4}$ except that the tertiary hydroxyl attached to C-3 was replaced by a hydroperoxyl. ${ }^{16} \mathrm{HMBC}$ correlations from $\mathrm{H}-17$ to C-1/C-2/ $\mathrm{C}-3$ confirmed the position of the hydroperoxyl. The relative stereochemistry of $\mathbf{5}$ was deduced from a 2D NOESY experiment, which indicated that Me-19, Me-20, and H-16 were on one side of the molecule, while Me-18, $\mathrm{H}-10$, and $\mathrm{H}-14$ were on the opposite side of the molecule. From the above data, pacificin $\mathrm{E}$ was thus formulated as $\mathbf{5}$.

Pacificin F (6) was shown to have the molecular formula of $\mathrm{C}_{20} \mathrm{H}_{34} \mathrm{O}_{2}$ by HREIMS and NMR spectra. The ${ }^{1} \mathrm{H}$ and ${ }^{13} \mathrm{C}$ NMR spectral data (Tables 1 and 2) exhibited some similarity to those of $\mathbf{2}$ except that the trisubstituted epoxide was replaced by a $E$-trisubstituted double bond. HMBC correlations (Supporting Information) from H-11 to C-9/C-10/C-12/C-13 confirmed the position of the $E$-trisubstituted double bond. The relative stereochemistry of $\mathbf{6}$ was determined on the basis of a 2D NOESY experiment (Supporting Information), which indicated that Me-19, Me20 , and $\mathrm{H}-16$ were on one side of the molecule, while $\mathrm{Me}$ $18, \mathrm{H}-10$, and $\mathrm{H}-14$ were on the opposite side of the molecule. From these data, pacificin F can be formulated as 6.

The molecular formula of pacificin $\mathrm{G}(\mathbf{7})$ was obtained from HRFABMS and NMR spectra. The ${ }^{1} \mathrm{H}$ and ${ }^{13} \mathrm{C}$ NMR spectral data (Tables 1 and 2) resembled those of 6 except for NMR signals due to the side chain terminus and an additional acetoxy group on the 10-membered ring. 2D COSY correlation (H-10/H-11) and HMBC correlations from $\mathrm{H}-11$ to C-9/C-10 confirmed the position of the acetoxy group. The side chain was identical to that of $\mathbf{3}$. The relative stereochemistry of $\mathbf{7}$ was deduced from a $2 \mathrm{D}$ NOESY experiment (Supporting Information), which indicated that Me-19, Me-20, $\mathrm{H}-11$, and $\mathrm{H}-16$ were on one side of the molecule, while Me-18, $\mathrm{H}-10$, and $\mathrm{H}-14$ were on the opposite side of the molecule. From the aforementioned data, pacificin $\mathrm{G}$ can be formulated as $\mathbf{7}$.

Pacificin $\mathrm{H}$ (8) was isolated as a colorless amorphous solid of molecular formula $\mathrm{C}_{20} \mathrm{H}_{36} \mathrm{O}_{5}$, as established by HRFABMS and NMR spectra. The ${ }^{1} \mathrm{H}$ and ${ }^{13} \mathrm{C}$ NMR 
Table 2. ${ }^{13} \mathrm{C}$ NMR Spectral Data of $\mathbf{1}-\mathbf{1 0}$

\begin{tabular}{|c|c|c|c|c|c|c|c|c|c|c|}
\hline & $\mathbf{1}^{a}$ & $\mathbf{2}^{a}$ & $\mathbf{3}^{a}$ & $\mathbf{4}^{a}$ & $\mathbf{5}^{a}$ & $6^{b}$ & $\mathbf{7}^{a}$ & $8^{a}$ & $\mathbf{9}^{a}$ & $10^{a}$ \\
\hline 1 & 25.7 & 30.0 & 24.5 & 111.8 & 114.7 & 29.8 & 24.5 & 114.9 & 25.8 & 30.0 \\
\hline 2 & 131.2 & 70.9 & 82.2 & 147.3 & 143.0 & 69.4 & 82.3 & 143.5 & 130.9 & 70.9 \\
\hline 3 & 125.0 & 141.3 & 136.7 & 76.9 & 90.4 & 141.7 & 136.3 & 90.6 & 125.5 & 140.6 \\
\hline 4 & 22.2 & 122.3 & 127.4 & 29.6 & 24.7 & 122.3 & 127.9 & 24.7 & 22.4 & 123.6 \\
\hline 5 & 46.6 & 48.1 & 49.1 & 41.7 & 41.7 & 48.6 & 49.0 & 40.5 & 45.9 & 48.2 \\
\hline 6 & 34.7 & 35.3 & 35.7 & 34.3 & 34.3 & 36.0 & 36.4 & 35.1 & 35.9 & 36.8 \\
\hline 7 & 36.6 & 36.5 & 37.1 & 36.8 & 36.7 & 37.2 & 37.4 & 36.9 & 37.7 & 38.1 \\
\hline 8 & 35.4 & 35.5 & 35.4 & 35.4 & 35.4 & 36.0 & 36.4 & 35.1 & 36.4 & 36.4 \\
\hline 9 & 61.9 & 62.0 & 61.9 & 61.9 & 62.8 & 132.2 & 139.9 & 140.4 & 136.1 & 136.0 \\
\hline 10 & 66.2 & 66.4 & 66.3 & 66.3 & 66.3 & 127.2 & 125.8 & 125.7 & 126.1 & 126.1 \\
\hline 11 & 24.4 & 24.5 & 24.3 & 24.4 & 24.4 & 24.7 & 69.0 & 69.0 & 30.4 & 30.3 \\
\hline 12 & 41.7 & 41.8 & 41.7 & 42.1 & 42.2 & 44.4 & 49.0 & 49.0 & 40.4 & 40.5 \\
\hline 13 & 72.9 & 73.0 & 73.0 & 72.9 & 72.9 & 72.0 & 71.5 & 71.6 & 154.0 & 153.8 \\
\hline 14 & 28.8 & 28.9 & 28.9 & 28.6 & 28.9 & 30.5 & 30.3 & 30.3 & 24.9 & 25.0 \\
\hline 15 & 3.9 & 3.9 & 4.3 & 3.9 & 3.9 & 5.8 & 4.9 & 4.5 & 12.9 & 13.1 \\
\hline 16 & 27.1 & 27.0 & 27.8 & 27.0 & 26.9 & 27.5 & 28.0 & 27.1 & 35.5 & 35.9 \\
\hline 17 & 17.6 & 30.0 & 24.5 & 17.2 & 17.1 & 29.8 & 24.5 & 17.0 & 17.6 & 30.0 \\
\hline 18 & 19.4 & 19.3 & 19.5 & 19.6 & 19.5 & 15.5 & 20.3 & 19.3 & 18.4 & 17.6 \\
\hline 19 & 17.1 & 17.1 & 17.0 & 17.0 & 17.1 & 17.9 & 18.2 & 17.0 & 15.8 & 15.8 \\
\hline 20 & 20.6 & 20.5 & 20.6 & 20.7 & 20.7 & 19.9 & 21.3 & 21.3 & 103.2 & 103.3 \\
\hline \multirow[t]{2}{*}{ OAc } & & & & & & & 21.4 & 21.4 & & \\
\hline & & & & & & & 170.5 & 170.4 & & \\
\hline
\end{tabular}

${ }^{a}$ Recorded in $\mathrm{CDCl}_{3}$ at $75 \mathrm{MHz}$ (assigned by DEPT, COSY, HSQC, and HMBC experiments). ${ }^{b}$ Recorded in acetone- $d_{6}$ at $75 \mathrm{MHz}$ (assigned by DEPT, COSY, HSQC, and HMBC experiments).

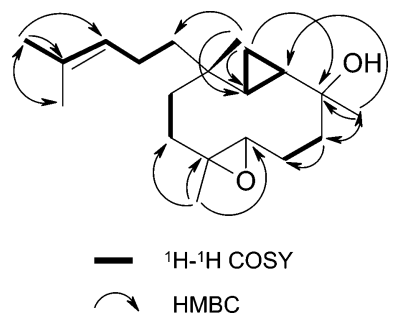

Figure 1. Key COSY and HMBC correlations of $\mathbf{1}$.

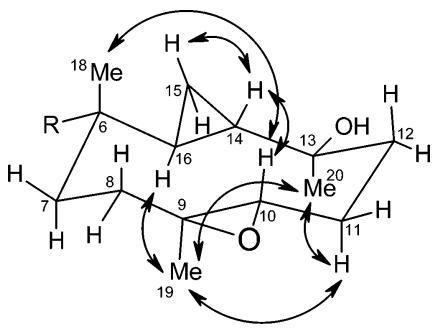

Figure 2. Selected NOESY correlations of $\mathbf{1}$.

spectral data (Tables 1 and 2) were quite similar to those of 7 except for NMR signals due to the side chain. HMBC correlations from $\mathrm{H}-17$ to $\mathrm{C}-1 / \mathrm{C}-2 / \mathrm{C}-3$ confirmed the 3-hydroperoxyisopentenyl side chain. The relative stereochemistry of $\mathbf{8}$ was established by a 2D NOESY experiment, which indicated that $\mathrm{Me}-19, \mathrm{Me}-20, \mathrm{H}-11$, and $\mathrm{H}-16$ were on one side of the molecule, while Me-18, H-10, and H-14 were on the opposite side of the molecule. From these data, pacificin $\mathrm{H}$ was formulated as 8 .

The ${ }^{1} \mathrm{H}$ and ${ }^{13} \mathrm{C}$ NMR spectral data (Tables 1 and 2 ) of pacificin $\mathrm{H}(\mathbf{9})$ were identical with those of an acetylation byproduct of an isolate from an octocoral Alcyonium palmatum..$^{15}$ However, after our detailed analysis of the 2D NMR spectra of $\mathbf{9}$, the ${ }^{1} \mathrm{H}$ and ${ }^{13} \mathrm{C}$ NMR chemical shifts at C-11, C-14, and C-16 should be revised as in Table 2. Compound $\mathbf{9}$ is a new natural product.

Pacificin I (10) analyzed for $\mathrm{C}_{20} \mathrm{H}_{32} \mathrm{O}$ by mass spectrometry in combination with interpretation of ${ }^{13} \mathrm{C}$ NMR data. The ${ }^{1} \mathrm{H}$ and ${ }^{13} \mathrm{C}$ NMR spectral data (Tables 1 and 2) were analogous to those of $\mathbf{9}$ except for NMR signals due to the side chain. COSY correlation between $\mathrm{H}-3 / \mathrm{H}-4$ and $\mathrm{H}-4 /$ $\mathrm{H}-5, \mathrm{HMBC}$ correlations from $\mathrm{H}-1 / \mathrm{H}-17$ to $\mathrm{C}-2 / \mathrm{C}-3$ and $\mathrm{H}-5$ to $\mathrm{C}-3 / \mathrm{C}-6 / \mathrm{C}-7$, and a $J_{3,4}$ of $15.6 \mathrm{~Hz}$ placed an $E$ double bond between $\mathrm{C}-3$ and $\mathrm{C}-4$. The relative stereochemistry of 9 was determined by a 2D NOESY experiment, which indicated that $\mathrm{Me}-19, \mathrm{Me}-20$, and $\mathrm{H}-16$ were on one side of the molecule, while Me-18, $\mathrm{H}-10$, and $\mathrm{H}-14$ were on the opposite side of the molecule. Therefore, the structure of pacificin I was established as $\mathbf{1 0 .}$

Pacificins $\mathrm{C}$ and $\mathrm{H}$ exhibited cytotoxicity against P-388 cells with $\mathrm{ED}_{50}$ 's of 1.44 and $2.01 \mu \mathrm{g} / \mathrm{mL}$, respectively. The other isolates were inactive against P-388 and HT-29 cell lines.

\section{Experimental Section}

General Experimental Procedures. Optical rotations were determined on a JASCO DIP-181 polarimeter. IR spectra were recorded on a Hitachi 26-30 spectrophotometer. The NMR spectra were recorded on a Bruker Avance 300 NMR spectrometer at $300 \mathrm{MHz}$ for ${ }^{1} \mathrm{H}$ and $75 \mathrm{MHz}$ for ${ }^{13} \mathrm{C}$, respectively, using TMS as internal standard. EIMS spectra were obtained with a JEOL JMS-SX/SX 102A mass spectrometer at $70 \mathrm{eV}$. Si gel 60 (Merck, 230-400 mesh) was used for column chromatography; precoated Si gel plates (Merck, Kieselgel 60 $\mathrm{F}_{254}, 0.25 \mathrm{~mm}$ ) were used for TLC analysis.

Animal Material. The soft coral N. pacifica was collected at Green Island, off Taiwan, in March 2002, at a depth of $5 \mathrm{~m}$ and was stored for 1 week in a freezer until extraction. A voucher specimen, NSUGN-058, was deposited in the Department of Marine Resources, National Sun Yat-sen University, Taiwan.

Extraction and Isolation. The bodies of the soft coral $N$. pacifica were freeze-dried to give $1.10 \mathrm{~kg}$ of a solid, which was extracted with $\mathrm{CH}_{2} \mathrm{Cl}_{2}(3.0 \mathrm{~L} \times 3$, overnight for each cycle $)$ at room temperature. After removal of solvent in vacuo, the residue $(47 \mathrm{~g})$ was chromatographed over Si gel 60 using $n$-hexane-EtOAc and $\mathrm{MeOH}-$ EtOAc mixtures as eluting solvents. Elution by $n$-hexane-EtOAc (85:15) afforded fractions containing 9. Elution by $n$-hexane-EtOAc (65:35) afforded fractions containing $\mathbf{1}, \mathbf{7}$, and $\mathbf{8}$. Elution by $n$-hexaneEtOAc (55:45) afforded fractions containing 6 and 10. Elution by $n$-hexane-EtOAc (35:65) afforded fractions containing $\mathbf{2}-\mathbf{5}$. Compound 1 (360 mg, 7.6\%) was further purified by Si gel column chromatography, eluting with $n$-hexane-acetone (4:1). Compounds 2 (3 mg, 0.006\%), 3 (3 mg, 0.006\%), 4 (5 mg, $0.011 \%)$, and $\mathbf{5}(6 \mathrm{mg}, 0.013 \%)$ were further purified by HPLC (LiChrosorb Si 60, $7 \mu \mathrm{m}, 25 \times 250 \mathrm{~mm}$ ), eluting with $n$-hexane-acetone (3:1). Compound 6 (3 mg, 0.006\%) was further 
purified by HPLC (LiChrosorb RP-18, $7 \mu \mathrm{m}, 25 \times 250 \mathrm{~mm}$ ), eluting with $\mathrm{MeOH}-\mathrm{H}_{2} \mathrm{O}$ (90:10). Compounds 7 (4 mg, 0.009\%) and $8(3 \mathrm{mg}, 0.006 \%)$ were further purified by HPLC ( $\mathrm{Li}-$ Chrosorb RP-18, $7 \mu \mathrm{m}, 25 \times 250 \mathrm{~mm}$ ), by eluting with $\mathrm{MeOH}-$ $\mathrm{H}_{2} \mathrm{O}$ (73:27). Compound 9 (20 mg, 0.042\%) was further purified by $\mathrm{Si}$ gel column chromatography, eluting with $n$-hexaneEtOAc (9:1). Compound 10 (4 mg, 0.009\%) was further purified by HPLC (LiChrosorb RP-18, $7 \mu \mathrm{m}, 25 \times 250 \mathrm{~mm}$ ), eluting with $\mathrm{MeOH}-\mathrm{H}_{2} \mathrm{O}(90: 10)$.

Pacificin A (1): $[\alpha]^{25}{ }_{\mathrm{D}}-62^{\circ}\left(c 0.2, \mathrm{CHCl}_{3}\right)$; IR (neat) $v_{\max }$ $3450 \mathrm{~cm}^{-1} ;{ }^{1} \mathrm{H}$ NMR, see Table $1 ;{ }^{13} \mathrm{C}$ NMR, see Table 2; EIMS $\mathrm{m} / z 306[\mathrm{M}]^{+}$(9), 288 (12), 270 (32), 81 (100); HREIMS m/z 306.2558 (calcd for $\mathrm{C}_{20} \mathrm{H}_{34} \mathrm{O}_{2}, 306.2550$ ).

Pacificin B (2): $[\alpha]^{25} \mathrm{D}-53^{\circ}\left(c 0.2, \mathrm{CHCl}_{3}\right)$; IR (neat) $v_{\max }$ $3520 \mathrm{~cm}^{-1}$; ${ }^{1} \mathrm{H}$ NMR, see Table $1 ;{ }^{13} \mathrm{C}$ NMR, see Table 2; EIMS $\mathrm{m} / z 322[\mathrm{M}]^{+}$(3), 304 (8), 81 (100); HREIMS m/z 322.2492 (calcd for $\mathrm{C}_{20} \mathrm{H}_{34} \mathrm{O}_{3}, 322.2499$ ).

Pacificin C (3): $[\alpha]^{25}{ }_{\mathrm{D}}-46^{\circ}\left(c 0.1, \mathrm{CHCl}_{3}\right)$; IR (neat) $v_{\max }$ $3480 \mathrm{~cm}^{-1} ;{ }^{1} \mathrm{H}$ NMR, see Table $1 ;{ }^{13} \mathrm{C}$ NMR, see Table 2; HRFABMS $\mathrm{m} / \mathrm{z} 339.2529$ (calcd for $\mathrm{C}_{20} \mathrm{H}_{35} \mathrm{O}_{4}, 339.2526$ ).

Pacificin D (4): $[\alpha]^{25}{ }_{\mathrm{D}}-43^{\circ}\left(c 0.2, \mathrm{CHCl}_{3}\right)$; IR (neat) $v_{\max }$ $3490 \mathrm{~cm}^{-1} ;{ }^{1} \mathrm{H}$ NMR, see Table $1 ;{ }^{13} \mathrm{C}$ NMR, see Table 2 ; EIMS $\mathrm{m} / \mathrm{z} 322[\mathrm{M}]^{+}(3), 304(6), 216$ (12), 81 (100); HREIMS $\mathrm{m} / \mathrm{z}$ 322.2495 (calcd for $\mathrm{C}_{20} \mathrm{H}_{34} \mathrm{O}_{3}, 322.2499$ ).

Pacificin E (5): $[\alpha]^{25}{ }_{\mathrm{D}}-38^{\circ}\left(c 0.1, \mathrm{CHCl}_{3}\right)$; IR (neat) $v_{\max }$ $3510 \mathrm{~cm}^{-1} ;{ }^{1} \mathrm{H}$ NMR, see Table $1 ;{ }^{13} \mathrm{C}$ NMR, see Table 2 ; HRFABMS m/z 339.2532 (calcd for $\mathrm{C}_{20} \mathrm{H}_{35} \mathrm{O}_{4}, 339.2526$ ).

Pacificin F (6): $[\alpha]^{25}{ }_{\mathrm{D}}-51^{\circ}\left(c 0.2, \mathrm{CHCl}_{3}\right)$; IR (neat) $v_{\max }$ $3460 \mathrm{~cm}^{-1} ;{ }^{1} \mathrm{H}$ NMR, see Table $1 ;{ }^{13} \mathrm{C}$ NMR, see Table 2 ; EIMS $\mathrm{m} / \mathrm{z} 306[\mathrm{M}]^{+}$(4), $288(6), 271(12), 215(8), 189(70), 95$ (100); HREIMS $m / z 306.2543$ (calcd for $\mathrm{C}_{20} \mathrm{H}_{34} \mathrm{O}_{2}, 306.2550$ ).

Pacificin G (7): $[\alpha]^{25} \mathrm{D}-26^{\circ}\left(c 0.2, \mathrm{CHCl}_{3}\right)$; IR (neat) $v_{\max }$ $3480,1730 \mathrm{~cm}^{-1} ;{ }^{1} \mathrm{H}$ NMR, see Table $1 ;{ }^{13} \mathrm{C}$ NMR, see Table 2; HRFABMS $m / z 381.2638$ (calcd for $\mathrm{C}_{22} \mathrm{H}_{37} \mathrm{O}_{5}, 381.2631$ ).

Pacificin H (8): $[\alpha]^{25} \mathrm{D}-18^{\circ}\left(c 0.1, \mathrm{CHCl}_{3}\right)$; IR (neat) $v_{\max }$ 3550, $1732 \mathrm{~cm}^{-1} ;{ }^{1} \mathrm{H}$ NMR, see Table $1 ;{ }^{13} \mathrm{C}$ NMR, see Table 2; HRFABMS m/z 381.2636 (calcd for $\mathrm{C}_{22} \mathrm{H}_{37} \mathrm{O}_{5}, 381.2631$ ).

Pacificin I (9): $[\alpha]^{25} \mathrm{D}-28^{\circ}\left(c 0.1, \mathrm{CHCl}_{3}\right) ;{ }^{1} \mathrm{H} \mathrm{NMR}$, see Table 1; ${ }^{13} \mathrm{C}$ NMR, see Table 2; EIMS $m / z 272[\mathrm{M}]^{+}(9), 257$ (12), 95 (100).

Pacificin J (10): $[\alpha]^{25} \mathrm{D}-22^{\circ}\left(c 0.2, \mathrm{CHCl}_{3}\right)$; IR (neat) $v_{\max }$ $3450 \mathrm{~cm}^{-1} ;{ }^{1} \mathrm{H}$ NMR, see Table $1 ;{ }^{13} \mathrm{C}$ NMR, see Table 2; EIMS $\mathrm{m} / z 288[\mathrm{M}]^{+}$(3), 270 (6), 220 (12), 95 (100); HREIMS $\mathrm{m} / \mathrm{z}$ 288.2440 (calcd for $\mathrm{C}_{20} \mathrm{H}_{32} \mathrm{O}, 288.2445$ ).

Cytotoxicity Testing. P-388 cells were kindly supplied by J. M. Pezzuto, Department of Medicinal Chemistry and
Pharmacognosy, University of Illinois at Chicago; A549 and HT-29 were purchased from the American Type Culture Collection. Cytotoxic assays were carried out according to the procedure described previously. ${ }^{14}$ Three concentrations (50, 5, and $0.5 \mu \mathrm{g} / \mathrm{mL}$ ) of the tested compounds were used in the cytotoxicity assays.

Acknowledgment. We thank J. M. Pezzuto, Department of Medicinal Chemistry and Pharmacognosy, University of Illinois at Chicago, for the provision of P-388 cell lines. This work was supported by grants from the National Science Council of Taiwan awarded to C.-Y.D.

Supporting Information Available: ${ }^{1} \mathrm{H}$ NMR, ${ }^{13} \mathrm{C}$ NMR, COSY, HSQC, HMBC, and ${ }^{13} \mathrm{C}-{ }^{13} \mathrm{C}$ homonuclear shift correlation 2D spectrum (INADEQUATE) of $\mathbf{1}$. This material is available free of charge via the Internet at http://pubs.acs.org.

\section{References and Notes}

(1) Coll, J. C.; Bowden, B. F.; Tapiolas, D. M.; Willis, R. H. Tetrahedron 1985, 41, 1085-1092.

(2) Poet, S. E.; Ravi, B. N. Aust. J. Chem. 1982, 35, 77-83.

(3) Ahond, A.; Bowden, B. F.; Coll, J. C.; Fourneron, J.; Mitchell, S. J. Aust. J. Chem. 1981, 34, 2657-2664.

(4) Blackman, A. J.; Bowden, B. F.; Coll, J. C.; Frick, B.; Mahendran, M.; Mitchell, S. J. Aust. J. Chem. 1982, 35, 1873-1880.

(5) Kitagawa, I.; Cui, Z.; Son, B. W.; Kobayashi, M.; Kyogoku, Y. Chem Pharm. Bull. 1987, 35, 124-135.

(6) Bowden, B. F.; Coll, J. C.; Mitchell, S. J. Aust. J. Chem. 1980, 33, $1833-1839$

(7) Handayani, D.; Edrada, R. A.; Proksch, P.; Wray, V.; Witte, L. J. Nat. Prod. 1997, 60, 716-718.

(8) Duh, C.-Y.; Wang, S.-K.; Weng, Y.-L. Tetrahedron Lett. 2000, 41, $1401-1404$

(9) Duh, C.-Y.; Wang, S.-K.; Weng, Y.-L.; Chiang, M. Y.; Dai, C.-F. J. Nat. Prod. 1999, 62, 1518-1521

(10) Rao, M. R.; Venkatesham, U.; Venkateswarlu, Y. J. Nat. Prod. 1999, $62,1584-1585$

(11) Zhang, W.-H.; Williams, I. D.; Che, C.-T. Tetrahedron Lett. 2001, 42, 4681-4686.

(12) Duh, C.-Y.; Wang, S.-K.; Chu, M.-J.; Sheu, J.-H. J. Nat. Prod. 1998 $61,1022-1024$

(13) Geran, R I.; Greenberg, N. H.; MacDonald, M. M.; Schumacher, A M.; Abbott, B. J. Cancer Chemother. Rep. 1972, 3, 1-91.

(14) Hou, R.-S.; Duh, C.-Y.; Chiang, M. Y.; Lin, C.-N. J. Nat. Prod. 1995, $58,1126-1130$

(15) Zubia, E.; Spinella A.; Guisto, G. B.; Crispino, A.; Cimino, G. Tetrahedron Lett. 1994, 35, 7069-7072

(16) Sheu, J.-H.; Huang, S.-Y.; Duh, C.-Y. J. Nat. Prod. 1996, 59, 23-26.

NP040160E 